${ }^{1}$ Department of Internal Medicine, PGIMER \& Dr Ram Manohar Lohia Hospital, New Delhi, India

${ }^{2}$ Department of Medicine, PGIMER \& Dr Ram Manohar Lohia Hospital, New Delhi, India

\section{Correspondence to}

Dr Naveen Kumar,

docnaveen2605@yahoo.co.in
To cite: Sundriyal D,

Kumar N,

Chandrasekharan $\mathrm{A}$, et al. BMJ Case Rep Published online: [please include Day Month Year] doi:10.1136/ bcr-2013-200163

\title{
Mauskopf facies
}

\author{
Deepak Sundriyal, ${ }_{1}^{1}$ Naveen Kumar, ${ }_{1}^{1}$ Arun Chandrasekharan, ${ }^{2}$ \\ Adesh Kumar Gadpayle ${ }^{2}$
}

\section{DESCRIPTION}

An 18-year-old girl presented with a 15-month history of swelling in both hands and feet, decreased opening of mouth and ulceration of the tips of fingers. She also gave a history of bluish discolouration of the fingers and toes, and pain on exposure to cold. She had expressionless face (reduced mobility of eyelid, check and mouth) with taut, shiny skin and loss of wrinkles. Her nose was pinched with a beak like appearance (figure 1). There was thinning of lips (figure 1) with reduced oral aperture (figure 2). Fingers and toes were indurated and had ulceration and necrosis. Raynaud's phenomenon was demonstrated. A full thickness skin biopsy was suggestive of the expansion of the dermis due to the presence of thick bundles of collagen with loss of fat. Anticentromere antibodies were detected. The diagnosis of systemic sclerosis is usually made on clinical grounds in a patient with typical Mauskopf facies, Raynaud's phenomenon and digital changes.

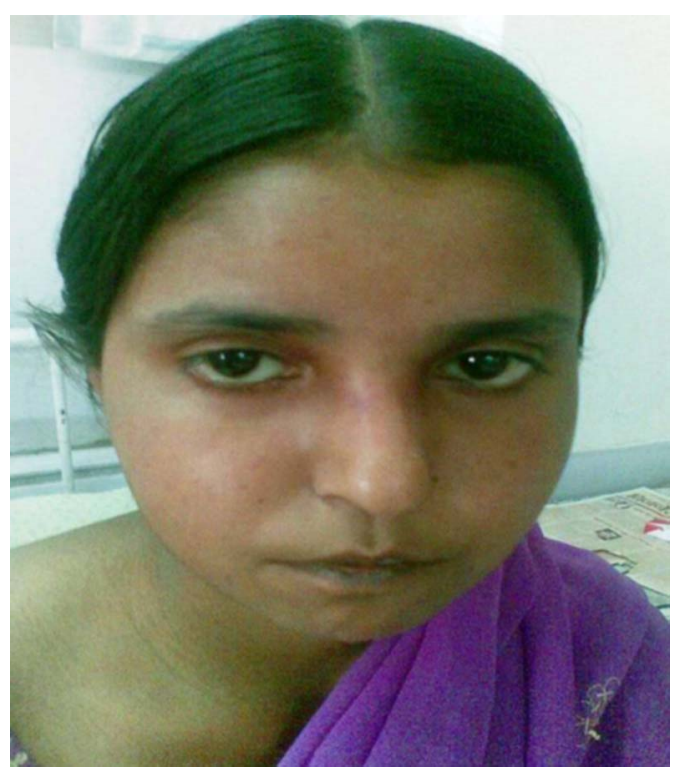

Figure 1 Expressionless face with taut, shiny skin and beak-shaped nose. There is also thinning of lips.

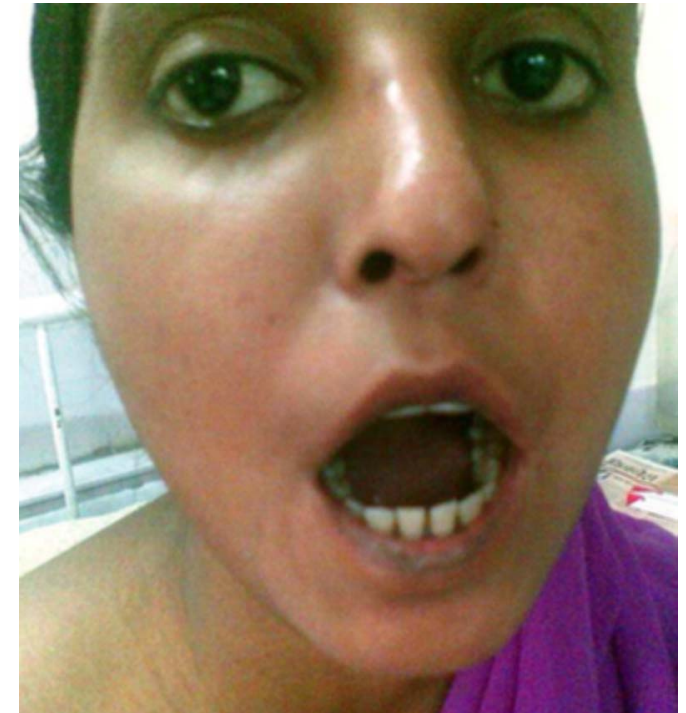

Figure 2 Mouth opening was reduced.

A full thickness biopsy of the skin may be required in some patients. It is important to differentiate between the limited cutaneous and diffuse systemic type of subsets, as prognosis is better with the former.

\section{Learning points}

- These constellations of skin changes, known as Mauskopf facies, are pathgnomonic of systemic sclerosis.

- Their presences easily differentiate diffuse scleroderma from limited cutaneous variant.

Contributors All authors contributed significantly in patient management and treatment, concept of paper, acquisition of data, drafting the article, revision and final approval of the manuscript.

\section{Competing interests None.}

Patient consent Obtained.

Provenance and peer review Not commissioned; externally peer reviewed. 


\section{Images in...}

Copyright 2013 BMJ Publishing Group. All rights reserved. For permission to reuse any of this content visit http://group.bmj.com/group/rights-licensing/permissions.

BMJ Case Report Fellows may re-use this article for personal use and teaching without any further permission.

Become a Fellow of BMJ Case Reports today and you can:

- Submit as many cases as you like

- Enjoy fast sympathetic peer review and rapid publication of accepted articles

- Access all the published articles

- Re-use any of the published material for personal use and teaching without further permission

For information on Institutional Fellowships contact consortiasales@bmjgroup.com

Visit casereports.bmj.com for more articles like this and to become a Fellow 